\title{
AUGUST 1961
}

\section{INTERNATIONAL REVIEW}

\author{
OF THE
}

\section{RED CROSS}

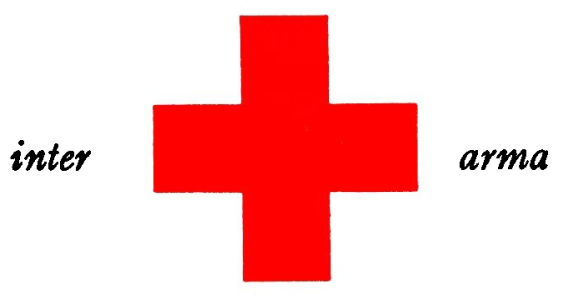

caritas

INTERNATIONAL COMMITTEE OF THE RED CROSS GENEVA 


\section{INTERNATIONAL COMMITTEE OF THE RED CROSS Geneva}

LEOPOLD BOISSIER, Doctor of Laws, Honorary Professor at the University of Geneva former Secretary-General to the Inter-Parliamentary Union, President (1946)

JACQUES CHENEVIERE, Hon. Doctor of Literature, Honorary Vice-President (1919)

LUCIE ODIER, Former Director of the District Nursing Service, Geneva Branch of the Swiss Red Cross (1930)

CARL J. BURCKHARDT, Doctor of Philosophy, former Swiss Minister to France (1933)

MARTIN BODMER, Hon. Doctor of Philosophy, Vice-President (1940)

ERNEST GLOOR, Doctor of Medicine, Vice-President (1945)

PAUL RUEGGER, former Swiss Minister to Italy and the United Kingdom, Member of the Permanent Court of Arbitration (1948), on leave

RODOLFO OLGIATI, Hon. Doctor of Medicine, former Director of the Don Suisse (1949)

MARGUERITE VAN BERCHEM, former Head of Section, Central Prisoners of War Agency (1951)

FREDERIC SIORDET, Lawyer, Counsellor of the International Committee of the Red Cross from 1943 to 1951 (1951)

GUILLAUME BORDIER, Certificated Engineer E.P.F., M.B.A. Harvard, Banker (1955)

ADOLPHE FRANCESCHETTI, Doctor of Medicine, Professor of clinical ophthalmology at Geneva University (1958)

HANS BACHMANN, Doctor of Laws, Assistant Secretary-General to the International Committee of the Red Cross from 1944 to 1946 (1958)

JACQUES FREYMOND, Doctor of Literature, Director of the Graduate Institute of International Studies, Professor at the University of Geneva (1959)

DIETRICH SCHINDLER, Doctor of Laws (1961)

SAMUEL GONARD, Colonel Commandant of an Army Corps, former Professor at the Federal Polytechnical School (1961)

HANS MEULI, Doctor of Medicine, Brigade Colonel, former Director of the Swiss Army Medical Service (1961)

\section{Direction:}

ROGER GALLOPIN, Doctor of Laws, Executive Director

JEAN S. PICTET, Doctor of Laws, Director for General Affairs

EDOUARD DE BONDELI, Assistant-Director; Financial and Administrative Services CLAUDE PILLOUD, Assistant-Director; Legal Department

\footnotetext{
${ }^{1}$ The figures in brackets represent the dates of nomination of the members of the International Committee
} 


\title{
INTERNATIONAL REVIEW OF THE RED CROSS
}

\author{
FIRST YEAR - No. 5 \\ AUGUST 1961 \\ * \\ $\operatorname{CONTENTS}$
}

Page

René Dovaz: Broadcasting in the service of the International Committee of the Red Cross . . . . . . . . . . . . . . .

Drs Bołko Jakovljević and Jovica Patrnogić: The urgent need to apply the rules of humanitarian law to so-called internal armed conflicts

INTERNATIONAL COMMITTEE OF THE RED CROSS

News Items . . . . . . . . . . . . . . . . . . . . . . . 258

The International Committee and the events in Bizerta . . . . . . 270

NEWS OF NATIONAL SOCIETIES

Ethiopia................. . 272

Portugal .................. . . 274

U.S.S.R. . . . . . . . . . . . . . . . . 277

\section{CHRONICLE}

The action of the League of Red Cross Societies on behalf of paralysed

Moroccans .................

278

A GLANCE THROUGH THE REVIEWS 


\section{FRENCH EDITION OF THE REVIEW}

The French edition of this Review is issued every month under the title of Revue internationale de la Croix-Rouge. It is, in principle, identical with the English edition and may be obtained under the same conditions.

\section{SUPPLEMENTS TO THE REVIEW}

\section{SPANISH}

Informaciones del mundo entero. - El Comité Internacional y los acontecimientos de Bizerta.

\section{GERMAN}

Nachrichten aus Nah und Fern. - Das Internationale Komitee und die Ereignisse in Biserta.

THE

INTERNATIONAL REVIEW OF THE RED CROSS

is published each month by the International Committee of the Red Cross

7. Avenue de la Paix, Geneva, Switzerland Postal Cheque No. I. 1767

Annual subscription : Sw. fr. 20.- Single copies Sw. fr. 2.-

Editor: JEAN-G. LOSSIER 